\title{
Pengaruh Pendidikan Kesehatan Metode Brainstorming dan Video terhadap Pengetahuan tentang Demam Berdarah pada Keluarga di Wilayah Kerja Puskesmas Puger Kabupaten Jember (The effect of Health Education Brainstorming Method and Video to the Knowledge about Dengue Hemorrhagic Fever in Families at Puger Public Health Center district of Jember)
}

\author{
Mukhammad Syafi'udin, Wantiyah, Kushariyadi \\ Fakultas Keperawatan Universitas Jember \\ JI. Kalimantan No. Kampus Tegal Boto Jember 37 Telp./Fax. (0331) 323450 \\ e-mail: wantiyah.psik@unej.ac.id
}

\begin{abstract}
The increasing cases of dengue hemorrhagic fever disease in both children and adults can be influenced by several factors. One of that influences increasing of dengue fever is lack of community knowledge about dengue hemorrhagic fever. Brainstorming is a form of discussion to gather the information from all participants. This research was to find out the effect of health education brainstorming method and video toward knowledge of dengue fever in the work area of Puger Public Health Center the distric of Jember. This was a quasy experiment research with two groups pretestposttest treatment design. The population were 88 families with 30 respondents as sample, conducted by simple random sampling, and divided into two groups 15 respondents as treatment group and 15 respondents as control group. Treatment group got health education brainstorming method combined with video and control group got health education brace method. Data were analyzed used t-test dependent and t-test independent with $95 \% \mathrm{Cl}(\alpha: 0,05)$. The result showed there were significant differences of knowledge before and after in both treatment group and control group ( $p: 0,000)$ and there were significant differences between treatment group and control after health education ( $p: 0,001)$. Overall, health education by brainstorming method and can improve knowledge of dengue hemorrhagic fever. It is recommended for nurses to do health education preventation and treatment about dengue hemorrhagic fever to improve knowledge people.
\end{abstract}

Keywords: health education brainstorming method and video, knowledge, dengue hemorrhagic fever 


\begin{abstract}
Abstrak
Semakin banyak kasus penyakit demam berdarah baik itu menjangkit anak-anak sampai orang dewasa disebabkan oleh beberapa faktor. Faktor yang mempengaruhi peningkatan kasus demam berdarah adalah kurangnya pengetahuan masyarakat tentang demam berdarah. Brainstorming merupakan suatu bentuk diskusi dalam rangka menghimpun informasi dari semua peserta. Penelitian ini adalah mengetahui pengaruh pendidikan kesehatan metode brainstorming dan video terhadap pengetahuan tentang demam berdarah pada keluarga di wilayah kerja Puskesmas Puger Kabupaten Jember. Jenis penelitian ini adalah quasi experiment dengan rancangan penelitian two group pretst-postest design. Populasi penelitian sebanyak 88 keluarga dengan sampel 30 responden dengan menggunakan simple random sampling yang dibagi menjadi dua kelompok. 15 kelompok perlakuan dan 15 kelompok kontrol. Kelompok perlakuan mendapatkan pendidikan kesehatan metode brainstorming dan video sedangkan kelompok kontrol mendapatkan pendidikan kesehatan metode ceramah. Data dianalisis menggunakan Uji t dependen dan tindependen dengan tingkat kepercayaan $95 \% \mathrm{Cl}(a: 0,05)$. Hasil menunjukkan ada perbedaan signifikan pengetahuan antara sebelum dan sesudah baik kelompok perlakuan dan kelompok kontrol ( $p$ : 000) dan ada perbedaan signifikan antara kelompok perlakuan dan kontrol setelah pendidikan kesehatan brainstorming dan video dengan hasil ( $p: 0.001$ ). Hasil keseluruhan pendidikan kesehatan metode brainstorming dan video dapat meningkatkan pengetahuan tentang demam berdarah. Rekomendasi kepada perawat dapat menggunakan pendidikan kesehatan metode brainstorming dan video kepada masyarakat.
\end{abstract}

Kata kunci: Pendidikan kesehatan metode brainstorming dan video, pengetahuan, demam berdarah

\section{Pendahuluan}

Pengetahuan adalah hasil tahu dan ini terjadi setelah orang melakukan penginderaan terhadap suatu objek tertentu [1]. Demam berdarah adalah suatu penyakit menular yang disebabkan oleh virus dengue yang ditularkan oleh nyamuk Aedes aegypti [2].

Ditinjau dari faktor manusia masalah datang karena kurangnya kepekaan masyarakat terhadap kesehatan lingkungan yang nantinya tanpa disadari akan berdampak buruk pada kesehatan. Kurangnya pengetahuan masyarakat tentang demam berdarah karena kuarngnya penyuluhan dari lembaga terkait [3]. Pengetahuan akan lebih langgeng dari pada perilaku yang tidak disadari oleh pengetahuan. Sebelum mengadopsi perilaku baru, didalam diri orang tersebut terjadi proses yang berurutan [4].

Fenomena yang ada dari hasil wawancara dengan petugas Puskesmas Puger didapatkan partisipasi masyarakat masih kurang Pemberantasan Sarang Nyamuk, umumnya masyarakat tidak tahu berapa kali harus melakukan PSN setiap bulannya. Akibatnya masyarakat Puger pada umumnya datang ke pelayanan kesehatan setelah mengalami demam selama 4 atau 5 hari. Hasil kuesioner dari 10 orang responden di wilayah kerja Puskesmas Puger didapatkan pengetahuan kurang sebanyak $60 \%$ dan pengetahuan baik sebanyak $40 \%$.
Pendidikan kesehatan adalah suatu proses perubahan pada diri manusia yang ada hubungannya dengan tercapainya tujuan kesehatan perorangan dan masyarakat [4]. Salah satu metode pendidikan kesehatan dalam keperawatan yang ada adalah metode brainstorming yaitu suatu diskusi dalam rangka menghimpun gagasan, informasi, pengetahuan, pengalaman dari semua peserta [5]. Video merupakan elemen multimedia yang paling dinamis dan realistis dibandingkan elemen-elemen lain. Penggunaan video dalam proses pendidikan kesehatan secara langsung dapat mempengauhi perasaan dan emosi para penggunanya secara lebih nyata [6].

Berdasarkan latar belakang tersebut peneliti bermaksud untuk mengadakan pendidikan kesehatan metode brainstorming dan video tentang demam berdarah serta menganalisis pengaruh pendidikan kesehatan metode brainstorming dan video terhadap pengetahuan keluarga tentang demam berdarah di Puskesmas Puger kabupaten Jember.

\section{Metode Penelitian}

Jenis penelitian ini adalah quasy experiment design dengan rancangan penelitian two group pretest-postest treatment design. Populasi penelitian sebanyak 88 
Syafi'udin, et al, Pengaruh Pendidikan Kesehatan Metode Brainstorming dan Video terhadap....

keluarga dengan sampel 30 orang menggunakan tehnik simple random sampling.

Penelitian ini dilaksanakan di wilayah kerja Puskesmas Puger Kabupaten Jember. Waktu Penelitian dilakukan pada bulan Februari sampai dengan Juni 2016. Waktu penelitian ini dihitung mulai dari pembuatan proposal sampai penyusunan laporan dan publikasi penelitian.

Teknik pengumpul data dalam penelitian ini menggunakan kuesioner karakteristik responden dan kuesioner pengetahuan. Data dianalisis dengan menggunakan uji $t$ independent dengan derajat kepercayaan 95\% $(\alpha=0,05)$. Etika penelitian pada penelitian ini peneliti menghormati maratabat responden, Peneliti meminimalisasi dampak yang merugikan bagi subyek, peneliti memberikan kesempatan bertanya kepada masing-masing responden, responden diberikan Informed consent sebelum sebelum mengikuti kegiatan penelitian.

\section{Hasil Penelitian \\ Karakteristik Responden}

Rerata usia responden dan Karakteristik responden berdasarkan umur, jenis kelamin, dan tingkat pendidikan.

Tabel 1. Rerata responden berdasarkan usia pada kelompok perlakuan dan kontrol

\begin{tabular}{lcccc}
\hline Variabel & Mean & Median & Modus & $\begin{array}{l}\text { Min- } \\
\text { Max }\end{array}$ \\
\hline Umur & & & & \\
Perlakuan & 33.60 & 34 & 23 & $21-46$ \\
Kontrol & 31.27 & 33 & 35 & $22-45$ \\
\hline
\end{tabular}

Tabel 2. Distribusi frekuensi karakteristik jenis kelamin dan tingkat pendidikan pada kelompok perlakuan dan kelompok kontrol.

\begin{tabular}{llcccc}
\hline No & Karakteristik & \multicolumn{2}{c}{ Perlakuan } & \multicolumn{2}{c}{ Kontrol } \\
\cline { 3 - 6 } & Responden & Orang & $\%$ & Orang & $\%$ \\
\hline $\mathbf{1}$ & Jenis Kelamin & & & & \\
& Laki-laki & 4 & 26,7 & 5 & 33,3 \\
& Perempuan & 11 & 73,3 & 10 & 66,7 \\
\hline & Total & $\mathbf{1 5}$ & $\mathbf{1 0 0}$ & $\mathbf{1 5}$ & $\mathbf{1 0 0}$ \\
\hline $\mathbf{2}$ & Tingkat & & & & \\
& Pendidikan & & & & \\
& SD & 4 & 26,7 & 10 & 66,7 \\
& SMP & 5 & 33,3 & 4 & 26,7 \\
& SMA & 5 & 33,3 & 1 & 6,7 \\
& PT & 1 & 6,7 & 0 & 0 \\
\hline & Total & $\mathbf{1 5}$ & $\mathbf{1 0 0}$ & $\mathbf{1 5}$ & $\mathbf{1 0 0}$ \\
\hline & & & & &
\end{tabular}

Tabel 3. Pengetahuan demam berdarah sebelum diberikan pendidikan kesehatan dan video pada kelompok perlakuan dan kontrol

\begin{tabular}{lcccl}
\hline Variabel & Mean & SD & $\begin{array}{l}\text { Min- } \\
\text { Mak }\end{array}$ & $\begin{array}{l}95 \% \\
\mathrm{Cl}\end{array}$ \\
\hline Perlakuan & 19,40 & 2,06 & $16-23$ & $\begin{array}{l}18,26- \\
20,54\end{array}$ \\
Kontrol & 16,33 & 1,45 & $14-19$ & $\begin{array}{l}15,53- \\
17,13\end{array}$ \\
\hline
\end{tabular}

Tabel 4. Pengetahuan keluarga tentang demam berdarah setelah diberikan pendidikan kesehatan pada kelompok perlakuan dan kelompok kontrol.

\begin{tabular}{lllll}
\hline Variabel & Mea & SD & $\begin{array}{l}\text { Min- } \\
\text { Mak }\end{array}$ & $\begin{array}{l}95 \% \\
\mathrm{Cl}\end{array}$ \\
\hline Perlakuan & 22,1 & 1,51 & $20-25$ & 21,30 \\
& 3 & & & - \\
Kontrol & 17,7 & 1,79 & $15-21$ & 22,97 \\
& 2 & & & 16,74 \\
& & & & - \\
& & & & 18,73 \\
\hline
\end{tabular}

Tabel 5. Pengetahuan keluarga tentang demam berdarah sebelum dan setelah diberikan pendidikan kesehatan metode brainstorming dan video pada kelompok perlakuan.

\begin{tabular}{lllll}
\hline Pengetahuan & SD & Cl 95\% & $p$ & Mean \\
& & & & \\
\hline Sebelum & 1,0 & $-3,31-$ & 0,00 & $-2,73$ \\
Setelah & 3 & $-2,16$ & 0 & \\
\hline
\end{tabular}

Hasil analisis tabel 5 didapatkan hasil uji $t$ dependent pada kelompok perlakuan dengan $p$ value $0,000<\alpha: 0,05$, artinya terdapat perbedaan yang signifikan sebelum dan setelah diberikan pendidikan kesehatan metode brainstorming dan video pada kelompok perlakuan. Hasil minus pada mean menunjukkan nilai pretest dikurangi nilai posttest.

Tabel 6. Pengetahuan keluarga tentang demam berdarah sebelum dan setelah diberikan pendidikan kesehatan metode ceramah pada kelompok kontrol.

\begin{tabular}{lllll}
\hline Pengetahuan & SD & Cl 95\% & $p$ & Mean \\
& & & & \\
\hline Sebelum & 0,9 & $-1,90-$ & 0,00 & $-1,40$ \\
Setelah & 1 & $-0,89$ & 0 & \\
\hline
\end{tabular}


Hasil analisis tabel 5 didapatkan hasil uji $t$ dependent pada kelompok perlakuan dengan $p$ value $0,000<\alpha: 0,05$, artinya terdapat perbedaan yang signifikan sebelum dan setelah diberikan pendidikan kesehatan metode ceramah pada kelompok kontrol. Hasil minus pada mean menunjukkan nilai pretest dikurangi nilai posttest.

Tabel 7 Perbedaan pengetahuan keluarga tentang demam berdarah pada kelompok perlakuan dan kelompok kontrol.

\begin{tabular}{|c|c|}
\hline Variabel & $\begin{array}{l}\text { Mean } \\
\text { Difference }\end{array}$ \\
\hline $\begin{array}{l}\text { Perlakuan } \\
\text { Kontrol }\end{array}$ & $-\quad 0,001$ \\
\hline $\begin{array}{l}\text { Hasil } \\
\text { independent } \\
\text { artinya terda } \\
\text { signifikan a } \\
\text { kelompok ko } \\
\text { kesehatan. }\end{array}$ & $\begin{array}{l}\text { analisis didapatkan nilai uji } t \\
\text { yaitu p value: } 0,001<\alpha: 0,05 \text {, } \\
\text { pat perbedaan pengetahuan yang } \\
\text { intara kelompok perlakuan dan } \\
\text { ontrol setelah diberikan pendidikan }\end{array}$ \\
\hline
\end{tabular}

\section{Pembahasan}

Pengetahuan sebelum dilakukan pendidikan kesehatan pada kelompok perlakuan dan kelompok kontrol

Hasil penelitian didapatkan tingkat pendidikan responden pada kelompok perlakuan yaitu, SD sebanyak 4 orang, SMP sebanyak 5 orang, SMA sebanyak 5 orang, dan Perguruan Tinggi sebanyak 1 orang. Sedangkan pada kelompok kontrol didapatkan tingkat pendidikan SD sebanyak 10 orang, SMP sebanyak 4 orang, dan SMA 1 orang. Nilai simpangan baku pada kelompok perlakuan adalah 2,06 dan kelompok kontrol adalah 1,45. Rata-rata pengetahuan pada kelompok perlakuan adalah 19,40 dan pada kelompok kontrol 16,33.

Hasil analisis menunjukkan simpangan baku pada kelompok perlakuan lebih besar dari pada kelompok kontrol. Menurut peneliti salah satu faktor yang mempengaruhi pengetahuan adalah tingkat pendidikan. Hal ini dapat diketahui pada karakteristik responden pada tingkat pendidikan. Tingkat pendidikan pada kelompok perlakuan lebih beragam di bandingkan dengan tingkat pendidikan pada kelompok kontrol hal sedangkan tingkat pengetahuan pada kelompok perlakuan dan kontrol rata-rata kategori pengetahuan cukup [7].
Pengetahuan sesudah
pendidikan kesehatan pada
dilakukan
perlakuan dan kelompok kontrol.
Hasil penelitian didapatkan tingkat pendidikan responden pada kelompok perlakuan yaitu, SD sebanyak 4 orang, SMP sebanyak 5 orang, SMA sebanyak 5 orang, dan Perguruan Tinggi sebanyak 1 orang. Sedangkan pada kelompok kontrol didapatkan tingkat pendidikan SD sebanyak 10 orang, SMP sebanyak 4 orang, dan SMA 1 orang. Nilai rata-rata pengetahuan pada kelompok perlakuan adalah 22,13 dengan simpangan baku 1,51 . Sedangkan pada kelompok kontrol rata-rata pengetahuan 17,72 dengan simpangan baku 1,79.

Menurut peneliti, hasil penelitian menunjukkan bahwa simpangan baku pada kelompok perlakuan semakin menurun sedangkan pada kelompok kontrol terjadi peningkatan. Selain faktor dari metode pendidikan kesehatan, tingkat pendidikan juga berpengaruh, pada kelompok perlakuan tingkat pendidikan responden lebih beragam sehingga pengetahuan responden semakin homogen, sedangkan pada kelompok kontrol tingkat pendidikan mayoritas pendidikan SD. Tingkat pengetahuan pada kelompok perlakuan masuk dalam kategori pengetahuan baik sedangkan pada kelompok kontrol masuk dalam kategori cukup [7].

Pengetahuan sebelum dan setelah dilakukan pendidikan kesehatan metode brainstorming dan video pada kelompok perlakuan

Hasil analisis didapatkan hasil uji $t$ dependen pada kelompok perlakuan dengan $p$ value $0,000<\alpha: 0,05$, artinya terdapat perbedaan yang signifikan sebelum dan setelah diberikan pendidikan kesehatan metode brainstorming dan video pada kelompok perlakuan. Hasil ini didukung oleh penelitian lain yang menunjukkan adanya perbedaan yang signifikan antara pengetahuan sebelum dan sesudah diberikan pendidikan kesehatan metode brainstorming dan video [8]. Kelebihan dari metode brainstorming adalah merangsang semua anggota untuk ambil bagian dalam pendidikan kesehatan [9]. 


\section{Pengetahuan sebelum dan setelah dilakukan pendidikan kesehatan metode ceramah pada kelompok kontrol}

Hasil analisis penelitian didapatkan hasil uji $t$ dependent pada kelompok perlakuan dengan $p$ value $0,000<\alpha: 0,05$, artinya terdapat perbedaan yang signifikan sebelum dan setelah diberikan pendidikan kesehatan metode ceramah pada kelompok kontrol. Hasil minus pada mean menunjukkan nilai pretest dikurangi nilai posttest.

Metode ceramah juga merupakan penuturan informasi dan paling efektif dalam mengatasi kelangkaan literatur atau rujukan yang sesuai dengan jangkakuan daya beli serta daya paham peserta didik. Beberapa kelebihan metode ceramah adalah pendidik mudah menguasai ruangan, pendidik mudah menerangkan banyak bahan ajar berjumlah besar, dapat diikuti oleh peserta dalam jumlah besar, serta mudah dilaksanakan [10].

\section{Perbedaan pengetahuan keluarga pada kelompok perlakuan dan kelompok kontrol}

Hasil analisis penelitian didapatkan uji $t$ independent perbedaan pengetahuan keluarga tentang demam berdarah pada kelompok perlakuan dan kelompok kontrol, yaitu $p$ value: $0,001<\alpha: 0,05$ artinya terdapat perbedaan pengetahuan yang signifikan antara kelompok perlakuan dan kelompok kontrol.

Menurut peneliti pendidikan kesehatan metode brainstorming dan video lebih mampu menyampaikan informasi dibandingkan dengan pendidikan kesehatan metode ceramah. Seseorang akan mampu mengingat $20 \%$ dari apa yang dilihat, $30 \%$ dari apa yang didengar, tetapi seseorang mampu mengingat $50 \%$ dari apa yang dilihat dan didengar [11].

Kelebihan dari pendidikan kesehatan metode brainstorming yaitu dapat membangkitkan pendapat baru, merangsang semua anggota untuk ambil bagian, menghasilkan reaksi rantai dalam pendapat, dapat dipakai kelompok besar maupun kecil, dan hanya sedikit peralatan yang diperlukan [9]. Sedangkan kelebihan media video adalah video mampu menggambarkan keadan nyata/menyerupai keadaan yang sebenarnya, video bersifat dinamis sehingga merangsang rasa dan mudah memberi kesan, video memungkinkan penerangan berulang-ulang, penggunaan media ini juga mempercepat kadar pemahaman seseorang, dan video mampu meraih emosi seseorang sehingga seseorang tidak langsung mengubah sikap seseorang dengan lebih mudah [11].
Kekurangan dari pendidikan kesehatan metode brainstorming adalah mungkin terbentuk kelompok yang terdiri atas orangorang yang tidak tahu apa-apa, diakui mungkin berputar-putar, laporan mungkin tidak tersusun baik, perlu belajar sebelumnya bila ingin mencapai hasil terbaik, dan biasanya memakan waktu untuk persiapan [10].

\section{Simpulan dan Saran}

Berdasarkan hasil penelitian dan pembahasan ada pengaruh pendidikan kesehatan metode brainstorming dan video terhadap pengetahuan tentang demam berdarah pada keluarga di wilayah kerja Puskesmas Puger Kabupaten Jember 2016.

Diharapkan bagi instansi kesehatan mampu melakukan tahapan pendidikan kesehatan pada tahap motivasi, yaitu perawat mampu mengubah perilaku sesuai dengan yang dianjurkan pendidik. Peneliti lanjutan dapat menggunakan metode pendidikan kesehatan yang lebih variatif dan disesuaikan dengan karakteristik responden.

\section{Daftar Pustaka}

[1] Notoadmodjo S. Pendidikan dan perilaku kesehatan. Jakarta: Rineka Cipta; 2003.

[2] Widoyono. Penyakit tropis epidemiologi, penularan, pencegahan, dan pemberantasannya. Jakarta: Erlangga; 2008.

[3] Soegeng. Demam berdarah dengue edisi 2. Surabaya: Airlangga University Press; 2008.

[4] Fitriani S. Promosi Kesehatan. Yogyakarta: Graha IImu; 2011.

[5] Notoadmodjo S. Promosi kesehatan dan ilmu perilaku. Jakarta: Rineka Cipta; 2007.

[6] Susilo R. Pendidikan kesehatan dalam keperawatan. Yogyakarta: Nuha Medika; 2011.

[7] Wawan A, Dewi M. Teori dan pengukuran pengetahuan, sikap dan perilaku manusia. Yogyakarta: Nuha Medika; 2010.

[8] Hapsari. Pengaruh metode brainstorming disertai pemutaran video terhadap pengetahuan tentang gangguan akibat kurang iodium [internet]. 2011. [diambil tanggal 10 Februari 2016]; dari http://lib.unnes.ac.id/10197/1/7491.pdf.

[9] Maulana H. Promosi kesehatan. Jakarta: EGC; 2009.

[10] Simamora R. Pendidikan dalam keperawatan. Jakarta: EGC; 2008. 
Syafi'udin, et al, Pengaruh Pendidikan Kesehatan Metode Brainstorming dan Video terhadap....

[11] Indonesia. Dinas Pendidikan Nasional. Strategi pembelajaran dan pemilihannya. Jakarta: Depdiknas; 2008. 